\title{
Proteolytic System of Streptococcus thermophilus
}

\author{
G.M. Rodríguez-Serrano ${ }^{1}$, M. García-Garibay ${ }^{1}$, A.E. Cruz-Guerrero ${ }^{1}$, L. Gómez-Ruiz ${ }^{1}$, A. Ayala-Niño ${ }^{2}$,
} A. Castañeda-Ovando ${ }^{2}$, and L.G. González-Olivares ${ }^{2 *}$

${ }^{1}$ Departamento de Biotecnología Universidad Autónoma Metropolitana-Iztapalapa, Av. San Rafael Atlixco No. 186. Col. Vicentina, México D.F. 09340, México. CP 09340, México, Ciudad de México

${ }^{2}$ Centro de Investigaciones Químicas, Universidad Autónoma del Estado de Hidalgo, Mineral de la Reforma, Hidalgo, México

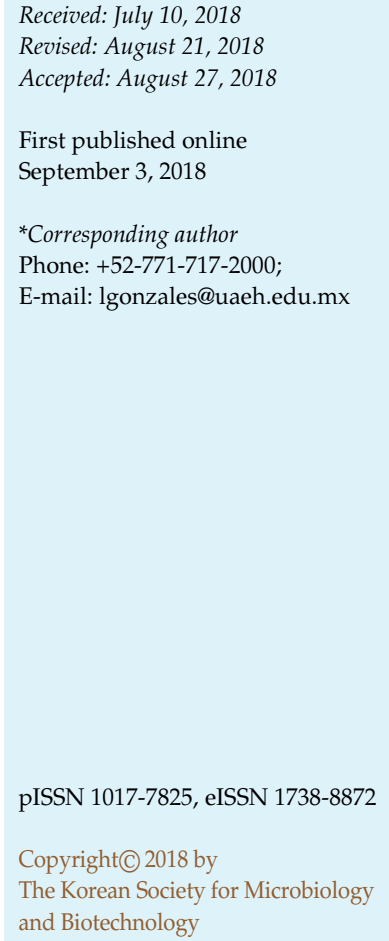

The growth of lactic acid bacteria (LAB) generates a high number of metabolites related to aromas and flavors in fermented dairy foods. These microbial proteases are involved in protein hydrolysis that produces necessary peptides for their growth and releases different molecules of interest, like bioactive peptides, during their activity. Each genus in particular has its own proteolytic system to hydrolyze the necessary proteins to meet its requirements. This review aims to highlight the differences between the proteolytic systems of Streptococcus thermophilus and other lactic acid bacteria (Lactococcus and Lactobacillus) since they are microorganisms that are frequently used in combination with other LAB in the elaboration of fermented dairy products. Based on genetic studies and in vitro and in vivo tests, the proteolytic system of Streptococcus thermophilus has been divided into three parts: 1) a serine proteinase linked to the cellular wall that is activated in the absence of glutamine and methionine; 2) the transport of peptides and oligopeptides, which are integrated in both the Dpp system and the Ami system, respectively; according to this, it is worth mentioning that the Ami system is able to transport peptides with up to 23 amino acids while the Opp system of Lactococcus or Lactobacillus transports chains with less than 13 amino acids; and finally, 3) peptide hydrolysis by intracellular peptidases, including a group of three exclusive of S. thermophilus capable of releasing either aromatic amino acids or peptides with aromatic amino acids.

Keywords: Proteolysis, lactic acid bacteria, Streptococcus thermophilus

\section{Introduction}

The proteolytic system of lactic acid bacteria (LAB) has been extensively studied using genetic and biochemical methods. Recently, research has been focused on the production of bioactive peptides by specific action of the proteolytic system over milk proteins during its fermentation $[1,2]$. In addition, several studies have been carried out in order to prove that the proteolytic systems of lactococci and lactobacilli hold a close relation [3, 4], while the proteolytic system of Streptococcus thermophilus presents other characteristics that makes it necessary to study it separately. The sequence of proteolytic reactions that occurs during streptococci as well as for lactococci and lactobacilli growth in milk is triggered by the action of extracellular endopeptidases. These proteinases release peptides derived from different caseins, which are natural substrate for intracellular peptidases that convert them into smaller peptides or, in case of an extent of hydrolysis, into amino acids. In general, the proteolytic system consists of serial chained reactions (Fig. 1), that are started by a serine proteinase proline-specific, linked to the cell wall; followed by the specific transport of dipeptides, tripeptides and oligopeptides, and finally, by the action of a countless number of intracellular peptidases and aminopeptidases $[1,5]$.

It has been clearly stated that many lactic acid bacteria are multi-auxotrophic for amino acids [6,7]. These requirements 


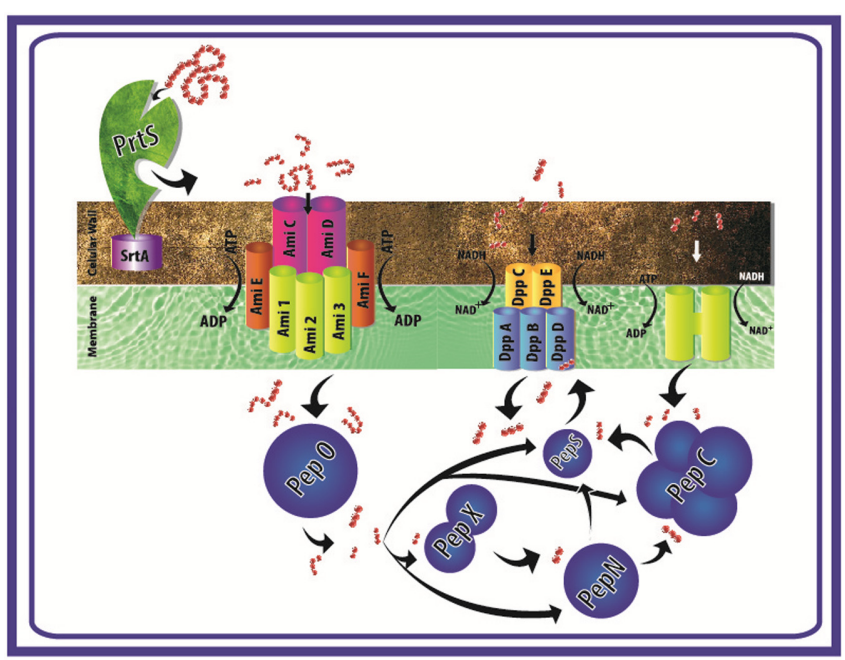

Fig. 1. Streptococcus thermophilus proteolytic system FOR. Graphic presentation of the proposed proteolytic system of Streptococcus thermophilus, its function and regulation. Model follows that proposed by Kuji et al. (1996). The system is divided into three steps. The first step is the breakdown of proteins by a proteinase PrtS, which is anchored at cell wall by sortase A (SrtA). The second step is transport of peptides and oligopeptides, the transport of peptides is integrated by the Dpp system with five proteins (DppA, DppB, DppC, DppD, and DppE) regulated by ATP and proton formation (NAD+); the oligopeptides transport is carried out by Ami system integrated in a operon system whit seven proteins (Ami1, Ami2, Ami3, AmiC, AmiD, AmiE, and AmiF) regulated by ATP and activate by sulfur amino acid presence. The transcriptional regulatory protein ComR associated to Ami system is regulated by the peptide ComS. Finally, third step is the cut of peptides by fourteen intracellular peptidases, where five (PepO, PepS, PepX, PepN, and PepC) have different characteristics and specificity to those of other lactic acid bacteria.

are specific for each strain, for example, some strains of Lactobacillus need only 4 amino acids, while others like Streptococcus thermophilus require from 14 to 20 depending on the strain $[3,8]$. The requirements for this bacterium are 4 times of glutamine and 14 times of methionine, in comparison to those reported for Lactobacillus spp. [8, 9]. On the other hand, $S$. thermophilus utilizes sulfured amino acids available in the medium to avoid energy consumption for their biosynthesis $[10,11]$.

Due to low activity of peptidases of $S$. thermophilus, the transport of amino acids and oligopeptides is more efficient than in other lactic acid bacteria, in which the intake of amino acids does not require energy consumption $[12,13]$. Besides, $S$. thermophilus has a specific intracellular peptidase for aromatic amino acid, such as phenylalanine and tryptophan $[14,15]$. The activity of this peptidase releases peptides with amino acids, which are essential for the growth of $S$. thermophilus. Also, a link between $S$. thermophilus growth in milk with high acidifying capacity and the presence of an efficient proteolytic system has been demonstrated [16].

\section{Cell Wall Proteinase of Lactic Acid Bacteria}

The degradation of caseins by LAB is triggered by an extracellular proteinase linked to the cell wall called PrtP in lactococci and lactobacilli $[1,4,17,18]$. In the case of S. thermophilus, the proteinase linked to the cell wall is called PrtS. This enzyme has specific differences with the cell wall proteinase of other lactic acid bacteria [19]. One of the most important differences is the isoelectric point (4.6) which is lower than the PrtP (4.8), that leads to the precipitation and subsequent inactivation of PrtS [20].

PrtP is classified according to its specificity in PI and PIII. It is a monomeric serine proteinase weighing between 180 and $190 \mathrm{kDa}$, although Laan and Konings [21] found some fractions associated with this proteinase during its isolation, suggesting that this fraction is monomeric only under certain conditions where the medium has neutral $\mathrm{pH}$. The gene that encodes for PrtP has been cloned and sequenced from some LAB. Primary structure of this enzyme consists of around 1,902 amino acids for lactococci and 1,946 to 1,962 amino acids for lactobacilli species [3]. Proteinases of different Lactococcus species present a similarity of $98 \%$ while the similarity of proteinases from lactobacillus species is $95 \%$, except the proteinase from Lactobacillus delbrïeckii, which presents a similarity of only $40 \%$ [22].

In a study on the proteolytic capacity of LAB, Shihata and Shah [23] observed that some streptococcal species showed higher proteolytic activity than other lactic acid bacteria, including lactobacilli and bifidobacteria. These results can be better explained with the requirements of glutamic acid and methionine, which are nearly five to six times higher for Streptococci than for the content of these amino acids released in milk ( $45 \mathrm{and}<1 \mathrm{mg} / \mathrm{ml}$, respectively) [24]. It is known that the prtS sequence encoding for the proteinase is similar to the sequences for other proteinases of lactic acid bacteria $[25,26]$.

PrtS is anchored to the cell wall of $S$. thermophilus by sortase A (SrtA) through a LPXTG sequence of the proteinase in the extreme C-terminal [27]. Likewise, it has been observed that this proteinase is necessary in the proto-cooperation systems like the yoghurt process [26]. Courtin et al. [26] tracked the changes in $\mathrm{pH}$ and the development of $S$. thermophilus and L. bulgaricus during milk fermentation and observed that the action of PrtS proteinase was essential for the growth of $S$. thermophilus in 
a pure culture, but it did not have any effect on its growth in a mixed culture with L. bulgaricus due to the presence of the particular proteinase PrtB of lactobacillus and PrtP of lactococcus homologue. However, proteinase PrtB of L. bulgaricus became essential for the growth of $S$. thermophilus in mixed cultures where a higher decrease of $\mathrm{pH}$ was found in pure cultures.

\section{Specificity of Streptococcus thermophilus Proteinase PrtS}

The products derived from the action of proteinases in milk are mainly from caseins $\alpha \mathrm{S} 1$ and $\beta$, which are the most abundant proteins. These proteins are preferred by the proteolytic system of LAB in over $80 \%$ of serum proteins [1, $5]$. In the case of $\beta$-casein $(B C N)$, some studies have revealed that the action of both PrtP and PrtS, can generate more than 100 oligopeptides with sizes from 4 to 30 residues, without any indications of the existence of di- and tripeptides but with trace concentrations of phenylalanine. Many peptides are generated from region 60-105 of this protein $[1,22,29]$. It has been observed in recent studies, that residues generated by the hydrolysis of sodium caseinate by $S$. thermophillus $4 \mathrm{~F} 44$ and $S$. termophilus LMD9- $\Delta s r t A$ PrtS, are peptides with different biological functions such as antihypertensive, anti-inflammatory, antioxidant, etc. $[20,30]$.

Regarding $\kappa$-casein $(\mathrm{KCN})$, the oligopeptides are generated from the region 96-106 [3]. $\mathrm{BCN}$ and $\mathrm{KCN}$ can be degraded by both types of PrtP of lactococci, PI and PIII; nevertheless, in the case of $\alpha$-casein (ACN) degradation can only occur through proteinase PIII and some proteinases with intermediate specificity between PI and PIII, since PII is unable to hydrolyze caseins $\alpha$-S1 and $\alpha$-S2. Nearly 23 oligopeptides coming from C-terminal end of ACN have been found [31].

In addition, specificity of PrtS of $S$. thermophilus is intermediate between that of PI and PIII of lactococcus. This enzyme has affinity to the three types of caseins [19, 32]. Fernandez-Espla et al. [19] observed that PrtS cuts links between an aromatic amino acid in position 1 (P1) and a proline in position 2 (P2), but becomes inactive when an amino acid is charged negatively in position 3 (P3). On the other hand, the sequence Ala-Pro-Tyr, that is preferred by PI for cutting, was the one with the highest activity for PrtS, whereas PIII, which shows more affinity for Ala-GluPro-Tyr-Phe, was poorly degraded by PrtS. There is in general a similar degradation of total caseins and $\mathrm{BCN}$ (degradation $\mathrm{BCN} /$ degradation of caseins $=0.8$ ), indicating that PIII PrtS does not have a marked preference for BCN. Also, depending on the conditions of reaction $(\mathrm{pH}$, saline concentration, etc.) PrtS is capable to hydrolyze $\alpha$ S1-casein in different sites of the fragment 1-23. However, with a $\mathrm{pH} 8$ it presents cutting characteristics in those of PI, and with a $\mathrm{pH} 6$ and with $\mathrm{pH}$ values close to those of cheese fermentation (5.2) and yogurt (4.0), the cuts are the same as those observed in PIII. This means that the cutting characteristics of this proteinase are a set of characteristics between PI and PIII of lactococci dependening on $\mathrm{pH}$ values $[16,31,33]$. This emphasizes that by changing the $\mathrm{pH}$ during the fermentation, the peptides toward PrtS can be modulated [34]. Besides these studies, the participation of PepS has been proven in the biosynthesis of peptidoglycan of the cell wall, which is essential for the development of S. thermophilus during fermentation [35].

Despite the previous information, not all the $S$. thermophilus strains possess PrtS, e.g., strain CNRZ1066 lacks prtS gene and, in contrast, strain LMD-9 displays strong proteolytic activity due to the presence and expression of prtS gene [36]. It has been shown that for high proteolytic activity, the presence of a putative CodY-box is necessary in their promoter region, which is a feature of the transcriptional pattern of CodY-regulated genes that are able to bind promoters of 14 genes belonging to the proteolytic system, including PrtS [37]. It has been shown that the interaction between S. thermophilus, with or without PrtS, and Lactobacillus, especially Lb. bulgaricus in yoghurt production, leads to strong proteolytic activities. This is because S. thermophilus efficiently consumes the peptides produced by $\operatorname{PrtB}$ and remains the dominant population during fermentation [38]. Not always is PrtS action desirable, such as in the case of biofilm formation, while heating sections of cheese-milk pasteurization equipment, it creates an acidic flavor and undesirable texture. It has also been proved that with the absence of this enzyme no biofilm is formed [39].

\section{Amino Acid and Peptide Transport System}

The transport of amino acids and peptides, through the cell membrane, is the second stage in the proteolytic system of LAB. This step includes a great number of subsystems for certain amino acids [1, 3, 5, 18]. In the case of lactococci and lactobacilli, at least 10 different amino acid transport systems with a high specificity for amino acids with similar structures have been found, for example: Glu/Gln, Leu/Ile/Val, Ser/Thr, Ala/Gly, and Lys/Arg [3]. These systems can be regulated by ATP hydrolysis in the cases of Glu/Gln, Asn, and Pro/Gly [18], or by protons in the case of Leu/Val/Ile, Ala/Gly, Ser/Thr, and Met, while the Arg/Orn is regulated by a concentration gradient in a passive transport [1]. 
The transport system of $S$. thermophilus has been little studied. However, the complex requirements of amino acids dictate that growth of $S$. thermophilus depends on a highly efficient transport system [10]. This system works with an external source of energy because $S$. thermophilus lacks an endogenous reserve of energy to perform this transport [40]. In particular, two energy inputs for amino acid transport have been reported in this genus. The first one, ATP and ATP metabolites are used directly as energy sources; the second one finds its explanation in Mitchell's Chemiosmotic Theory, where the formation of a proton is needed to generate the motive force that will accompany the transport of amino acids and short-chain peptides. This amino acid transport system depends on temperature, and $\mathrm{pH}$, where optimal temperature goes from $30^{\circ} \mathrm{C}$ to $45^{\circ} \mathrm{C}$, and decreases rapidly over $50^{\circ} \mathrm{C}$ in $\mathrm{S}$. faecalis [41].

\section{Di- and Tri-Peptide Transport System}

Di- and tri-peptide transport system is related to the transport of essential amino acids [42]. Studies on transport of hydrophilic di- and tripeptides in lactobacilli and lactococci have shown that this mechanism is regulated by the generation of protons. Dipeptide transport is carried out through an enzyme called DtpT that belongs to a family of enzymes called the PRT family. This group of enzymes is characterized by allowing the transport of hydrophilic diand tri-peptides, which are unrelated to the peptide transporters in other bacteria belonging to the $\mathrm{ABC}$ family. Through the analysis of the genomic sequence encoding the DtpT enzyme, it is known that this group of enzymes requires ATP hydrolysis to perform its function [3].

Studies of the genome sequence of some strains of $S$. thermophilus have revealed a relationship between protondependent enzymes and some of the ATP-dependent enzymes, all of them included in the ABC family [10]. In S. thermophilus, most dipeptide-carrying enzymes are organized in a complex of five proteins, which is associated with the cell membrane [43].

A genomic DNA fragment of $5.8 \mathrm{~kb}$ of $S$. thermophilus (serotype M49 group A, strain CS101) was sequenced, and 5 genes coding for proteins of the Dpp system (dppA to $d p p E)$ were found. They had a similarity of $17 \%$ to $54 \%$ compared to the enzyme sequence of the $\mathrm{ABC}$ transport group [42]. The organization of the five genes encoding system was confirmed in $S$. thermophilus, where the most abundant was $\operatorname{dpp} A$, similar to that found in the oligopeptide permease system in lactococci [43]. To verify the role of each unit in the system of Dpp, Podbielski and Bettina [42] carried out an insertional inactivation to create two
Streptococcus species (M2 and M49), which did not express the genes $d p p D$ and $d p p E$. They observed that in growth media with dipeptides, these species were unable to grow, hence their specificity towards dipeptides was detected.

\section{Oligopeptide Transport System}

The transport system of oligopeptides in LAB, particularly of lactobacilli and lactococci, has been one of the most studied [29]. It consists of five proteins (OppA, B, C, D, and $\mathrm{F})$, belonging to the $\mathrm{ABC}$ family which are ATP-dependent, as in the case of the proteins from the transport systems of amino acids and peptides [13]. This system has not been fully characterized, but it is known for its ability to transport oligopeptides with up to 12 amino acids into the cell [44].

In contrast, the oligopeptide transport system of $S$. thermophilus (Ami) is considered a more complex system since it allows the entry of peptide chains of up to 23 amino acids [13]. In the Ami system, as well as in the Opp system, a larger number of proteins are involved. The Ami system of Streptococcus thermophilus has a high similarity with the Ami system of S. pneumonia [10]. The main difference between these systems is that the first one possesses two more oligopeptide-binding proteins. These binding proteins, which are ATP-dependent, are associated with the cell membrane and they are also responsible for the activation of operons (AmiA1, AmiA2 and AmiA3) [45].

The operon structure of the Ami system makes it more efficient than the Opp operon in terms of amino acid transport into the cell [46]. This higher efficiency compensates for the lack of a proteinase such as PrtP present in other LAB [19]. It has been shown that in the Ami system, long-chain peptides with a negative charge cannot be transported into the cell. On the other hand, peptide chains between 1,000 and 3,000 Da with a net positive charge and hydrophobic peptides can be transported more efficiently [13]. This system is complemented with two proteins bound to the cell wall (AmiC and AmiD). When the operon is activated, as occurs when sulfur amino acids are present in the medium, these proteins change to an $\alpha$-helix conformation. This change allows them to act as a peptide binding permease, permitting the passing of peptides of up to 23 amino acids through the cell membrane. The energy required for their transport is also generated by the Ami operon through two ATP protein donors: AmiE and AmiF [43].

The existence of a gene regulatory system associated with the Ami system has been demonstrated. The gene regulatory mechanism involves the production, secretion 
and transport of ComS and this peptide regulates the activity of the ComR protein, which is in turn a natural regulator of the $S$. thermophilus transcription system [47].

\section{Peptidases of $S$. thermophilus}

Once the peptides have been transported into the microorganism, they must be fractionated to release the essential amino acids. This action is performed through a complex system of intracellular peptidases and aminopeptidases. Several studies have been conducted to isolate and identify enzymes that participate in this system. Their sequences, specificity and physicochemical characteristics have been described [29]. The proteolytic system of S. thermophilus consists of fourteen peptidases, of which, PepN, PepC, PepS, PepX, and PepO, have different characteristics and specificity compared to those of other LAB [48].

Aminopeptidase $\mathbf{N}(\mathrm{PepN})$. This peptidase of $S$. thermophilus is a $95 \mathrm{kDa}$ monomer with a maximum activity at $\mathrm{pH} 7$ and $37^{\circ} \mathrm{C}$. This peptidase is strongly inhibited by chelating agents, suggesting that it is a metallopeptidase. Furthermore, it has been shown that the presence of divalent ions such as $\mathrm{Co}^{2+}, \mathrm{Zn}^{2+}, \mathrm{Mn}^{2+}$ are able to restore its activity. This aminopeptidase has a high specificity for hydrophobic amino acids, particularly at the N-terminal, in low molecular weight peptides (chains of 4 to 6 amino acids). These characteristics placed it within the family of zinc metallopeptidase [49].

In contrast, aminopeptidase of $L$. lactis shows a preference for arginine dipeptide on the N-terminal residue but it is also capable of hydrolyzing peptides having lysine and leucine. This enzyme is able to cut amino acid $\mathrm{N}$-terminal residue in a wide range of sizes and compositions. Its activity has been directed to the hydrolysis of oligopeptides with proline at P1 and P2 [50]. Transcription analyses have proved that this aminopeptidase shows high homology with other peptidases reported in LAB [51, 52]. It has been revealed that the sequences encoding for this enzyme are kept in almost all LAB [53-55].

Aminopeptidase C (PepC). S. thermophilus PepC is similar to the lactococcal peptidase. This aminopeptidase has specificity for peptides with cysteine residues. One of the most significant differences between these peptidases is that aminopeptidase of $S$. thermophilus is not able to release proline residues at $\mathrm{pH} 7$ and $37^{\circ} \mathrm{C}$ [28].

Chapot-Chartier et al. [56] found that PepC of $S$. thermophilus has $70 \%$ homology with the sequence of PepC of Lactococcus lactis subsp. cremoris. Furthermore, it has been confirmed that the catalytic site of $S$. thermophilus
CNRZ 302 aminopeptidase maintains the same region for the cysteine proteinase of Lactococcus lactis subsp. cremoris. The biochemical characterization of this enzyme confirmed that the cloned peptidase is a thiol aminopeptidase with a molecular weight of $300 \mathrm{kDa}$ with a hexameric structure.

Aminopeptidase $C$ is usually a thiol peptidase of about $50 \mathrm{kDa}$ in all the LAB [54], which hydrolyzes dipeptides with Ala, Leu or Lys in the N-terminal position while being incapable of hydrolyzing hexapeptides. A notable difference in terms of the quaternary structure is the organization of the hexamer shown by the PepC of Streptococcus thermophilus, compared to tetramers organization in other species of LAB [3].

Peptidase PepS. This is a monomeric metallopeptidase of $45 \mathrm{kDa}$ which acts at $\mathrm{pH}$ between 7.5 and 8.5 , and at a temperature of $55^{\circ} \mathrm{C}$. It is characterized by being highly specific for peptides with arginine or aromatic amino acids at the N-terminal of the polypeptidic chain [19]. This aminopeptidase has a high homology with the family of intracellular aminopeptidases $\mathrm{T}$ of thermophilic bacteria ( $40 \%$ to $50 \%$ ), therefore it is classified within this family [57]. There are several examples of evidence where the molecular mass $(45 \mathrm{kDa})$ of the gene coding for this peptidase is very similar to that of other enzymes purified from the same family. Likewise, studies of the gene coding have shown there is no difference in the $\mathrm{N}$ - terminal sequence of PepS and other thermophilic enzymes [58]. Based on the amino acid sequence of PepS, it is assumed that it is intracellular [59].

Additionally, there is no associated hydrophobic sequence as it is found in the extracellular enzymes [60]. PepS can participate in the hydrolysis of peptides with high concentration of hydrophobic amino acids and thus releases smaller peptides with aromatic amino acids [61-63].

Peptidase PepX. This peptidase was purified first by Tsakalidou et al. [64] from Streptococcus thermophilus ACA-DC4. PepX is a peptidase that is classified in the same group of serine proteases and has been called aminopeptidase $X$ prolyl-dipeptidyl [65]. The specificity of this peptidase is over proline, and regardless of the adjacent amino acid, it hydrolyses the peptide bond at carboxyl side of the proline residue, cleaving dipeptidyl residue when this amino acid is the penultimate $\mathrm{N}$-terminal residue $[4,66]$. This enzyme consists of two subunits, each one with a molecular mass of $80 \mathrm{kDa}$. Its optimum activity is at $\mathrm{pH} 7$ and $50^{\circ} \mathrm{C}$ and it can be inactivated by compounds with sulfhydryl groups [66].

PepX isolated from LAB and other bacteria, yeast, and eukaryotes has been classified as serine proteinase based on the inhibitory effect of several compounds [64, 67-70]. 
The activation or inactivation of peptidases has been studied because it activates cheese ripening and yoghurt fermentation. Giannoglou et al. [71] showed that emergent technologies, such as high pressure, have the ability to increase or inactivate PepX depending on the range of pressure and temperature used, making small or high changes in the enzyme structure.

Oligopeptidase PepO. Oligopeptidase PepO of $S$. thermophilus is a metallopeptidase of $70 \mathrm{kDa}$, with a maximum activity at $\mathrm{pH} 6.5$ and $41^{\circ} \mathrm{C}$. This peptidase acts on oligopeptide chains of 5 to 30 amino acids and its specificity makes PepO a unique peptidase in the proteolytic system of $S$. thermophilus although this enzyme has certain homology with peptidases of the same group of other LAB [72], like that of L. lactis PepN proteolytic activity measured in vitro [51]. PepO activity is specific for peptides with arginine and methionine in the polypeptide chain $[72,73]$.

The proteolytic system of $S$. thermophilus is involved in the release of peptidic sequences from caseins and whey proteins during lactic acid fermentation. This microorganism is associated with other lactic acid bacteria worldwide in the production of fermented dairy products. Additionally, the whole action of each proteolytic system results in the release of amino acids that supply the metabolic needs of the microorganisms and potentially bioactive peptides. The study of bioactive peptides has developed much in the last decade; hence, the importance of knowing more about the characteristics of the proteolytic system of $S$. thermophilus.

\section{Conflict of Interest}

The authors have no financial conflicts of interest to declare.

\section{References}

1. Savijoki K, Ingmer H, Varmanen P. 2006. Proteolytic systems of lactic acid bacteria. Appl. Microbiol. Biotechnol. 71: 394-406.

2. Rojas-Ronquillo A, Cruz-Guerrero A, Flóres-Nájera A, Rodríguez-Serrano G, Gómez-Ruiz L, Reyes-Grajeda JP, et al. 2012. Antithrombotic and angiotensin-converting enzyme inhibitory properties of peptides released from bovine casein by Lactobacillus casei Shirota. Food Biotech. 26: 1-8.

3. Kunji ERS, Mierau I, Hagting A, Poolman B, Konings WN. 1996. The proteolytic system of lactic acid bacteria. Antonie Van Leewenhoek 70: 187-221.

4. Liu M, Bayjanov JR, Renckens B, Nauta A, Siezen RJ. 2010. The proteolytic system of lactic acid bacteria revisited: a genomic comparison. BMC Genomics 297: 164-172.

5. Gasson MJ, de Vos WM. 1994. The proteolytic system of lactic acid bacteria, pp. 169-210. In Gasson MJ, Vos WM (eds.), Genetics and Biotechnology of Lactic Acid Bacteria, Springer, Netehrlands.

6. Chopin A. 1993. Organization and regulation of genes for amino acid biosynthesis in lactic acid bacteria. FEMS Microbiol. Rev. 12: 21-37.

7. Leroy F, DeVuyst L. 2004. Lactic acid bacteria as functional starter cultures for the food fermentation industry. Trends Food Sci. Technol. 15: 67-78.

8. Letort C, Nardi M, Garault P, Monnet V, Juillard V. 2002. Casein utilization by Streptococcus thermophilus results in a diauxic growth in milk. Appl. Environ. Microbiol. 68: 3162-3165.

9. Monnet C, Mora D, Corrieu G. 2005. Glutamine synthesis is essential for growth of Streptococcus thermophilus in milk and is linked to urea catabolism. Appl. Environ. Microbiol. 71: 3376-3378.

10. Hols P, Hancy F, Fontaine L, Grossiord B, Prozzi D, Leblond-Bourget $\mathrm{N}$, et. al 2005. New insights in the molecular biology and physiology of Streptococcus thermophilus revealed by comparative genomics. FEMS Microbiol. Rev. 29: 435-463.

11. Herve-Jimenez L, Guillouard I, Guedon E, Gautier C, Boudebbouze S, Hols P, et. al 2008. Physiology of Streptococcus thermophilus during the late stage of milk fermentation with special regard to sulfur amino-acid metabolism. Proteomics 8: $4273-4286$.

12. Letort C, Juillard V. 2001. Development of a minimal chemically-defined medium for the exponential growth of Streptococcus thermophilus. J. Appl. Microbiol. 91: 1023-1029

13. Juille O, Le Bars D, Juillard V. 2005. The specificity of oligopeptide transport by Streptococcus thermophilus resembles that of Lactococcus lactis and not that of pathogenic streptococci. Microbiology 151: 1987-1994.

14. Motoshima H, Shiraishi T, Tsukasaki F, Kaminogawa S. 2003. Purification, characterization and gene cloning of lysil aminopeptidase from Streptococcus thermophilus YRC001. Biosci. Biotechnol. Biochem. 67: 772.782.

15. Zhang Q, Ren J, Zhao M, Zhao H, Regenstein JM, LiY, Wu J. 2011. Isolation and characterization of three novel peptides from casein hydrolysates that stimulate the growth of mixed cultures of Streptococcus thermophilus and Lactobacillus delbrueckii subsp. bulgaricus. J. Agric. Food Chem. 59: 7045-7053.

16. Dandoy D, Fremaux C, Henry-Frahan M, Horvath P, Boyaval P, Hols P, et al. 2011. The fast milk acidifying phenotype of Streptococcus thermophilus can be acquired by natural transformation of the genomic island encoding the cell-envelope proteinase PrtS. Microb. Cell Fact. 10: S21

17. Pritchard GG, Coolbear, T. 1993. The physiology and biochemistry of the proteolytic system in lactic acid bacteria. FEMS Microbiol. Rev. 12: 179-206.

18. Poolman B, Kunji ERS, Hagting A, Juillard V, Konings WN. 1995. The proteolytic pathway of Lactococcus lactis. Soc. Appl. Bacteriol. Symp. Ser. 24: 65S-75S

19. Fernandez-Espla MD, Garault P, Monnet V, Rul F. 2000. 
Streptococcus thermophilus cell anchored proteinase: release, purification and biochemical and genetic characterization. Appl. Environ. Microbiol. 66: 4772-4778.

20. Chang OK, Roux E, Awussi AA, Miclo L, Jardin J, Jameh N, et al. 2014. Use of a free form of the Streptococcus thermophilus cell envelope protease PrtS as a tool to produce bioactive peptides Int. Dairy J. 38: 104-115.

21. Laan H, Konings WN. 1989. The mechanism of proteinase release from Lactococcus lactis subsp. cremoris Wg2. Appl. Environ. Microbiol. 55: 3101-3106

22. Yamamoto N, Aquino A, Takano T. 1993. Purification and specificity of a cell-wall-associated proteinase from Lactobacillus helveticus CP790. J. Biochem. 114: 740-745.

23. Shihata A, Shah NP. 2000. Proteolytic profiles of yogurt and probiotic bacteria. Int. Dairy J. 10: 401-408.

24. Juillard V, Laan H, Kunji ERS, Jeronimus-Stratingh CM, Bruins AP, Konings WN. 1995. The extracellular PI-type proteinase of Lactococcus lactis hydrolyzes $\beta$-casein into more than one hundred different oligopeptides. J. Bacteriol. 12: 3472-3478.

25. Renault PG, Corthier N, Goupil C, Delorme C, Ehrlich SD. 1996. Plasmid vectors from Gram-positive bacteria switching from high low copy number. Gene 12: 175-182.

26. Courti P, Monnet V, Rull F. 2002. Cell-wall proteinases PrtS and PrtB have a different role in Streptococcus thermophilus/ Lactobacillus bulgaricus mixed cultures in milk. Microbiology 148: 3413-3421.

27. Chang OK, Perrin C, Galia W, Saulnier F, Miclo L, Roux E, et al. 2012. Release of the cell-envelope protease PrtS in the growth medium of Streptococcus thermophilus 4F44. Int. Dairy J. 148: 3413-3421.

28. Somkuti GA, Paul M. 2010. Enzymatic fragmentation of the antimicrobial peptides casocidin and isracidin by Streptococcus thermophilus and Lactobacillus delbrueckii ssp. Bulgaricus. Appl. Microbiol. Biotechnol. 87: 235-242.

29. Kunji ERS, Hagting A, DeVries CJ, Juillard V, Haandrikman AJ, Poolman B, et al. 1995. Transport of $\beta$-casein-derived peptides by the oligopeptide transport system is a crucial step in the proteolytic pathway of Lactococcus lactis. J. Biol. Chem. 27: 1569-1574.

30. Mukhopadhya A, Noronha N, Bahar B, Ryan BA, Kelly PM, O'Loughlin IB, et al. 2014. Anti-inflammatory effects of a casein hydrolysate and its peptide-enriched fractions on TNF $\alpha$-challenged Caco- 2 cells and LPS-challenged porcine colonic explants. Food Sci. Nutr. 2:712-723.

31. Monnet V, Ley JP, González S. 1992. Substrate specificity of the cell enveloped-located proteinase of Lactococcus lactis subsp lactis NCDO763. Int. J. Biochem. 24: 707-718.

32. Delorme C, Bartholini C, Bolotine A, Ehrlich SD, Renault P. 2010. Emergence of a cell wall protease in the Streptococcus thermophilus population. Appl. Environ. Microbiol. 76: 451-460.

33. Exterkate FA, Alting AC, Bruinenberg PG. 1993. Diversity of cell envelope proteinase specificity among strain of Lactococcus lactis and its relationship to charge characteristics of the substrate-binding region. Appl. Environ. Microbiol. 59: 3640-3647.

34. Hafezz Z, Cakir-Kiefer C, Girardet JM, Lecomte X, Galia W, Dary A, et al. 2015. New insights into the proteolytic system of Streptococcus thermophilus: use of Isracidin to characterize cell-associated extracellular peptidase activities. J. Agric. Food Chem. 63: 7522-7531.

35. Thomas S, Besset C, Courtin P, Rul F. 2010. The role of aminopeptidase PepS in the growth of Streptococcus thermophilus is not restricted to nitrogen nutrition. J. Appl. Microbiol. 108: 148-157.

36. Galia W, Perrin C, Genay M, Dary A. 2009. Variability and molecular typing of Streptococcus thermophilus strains displaying different proteolytic and acidifying properties. Int. Dairy. J. 19: 89-95.

37. Galia W, Jameh N, Perrin C, Genay M, Dary-Mourot A. 2016. Acquisition of PrtS in Streptococcus thermophilus is not enough in certain strains to achieve rapid milk acidification. Diary Sci. Technol. 96: 623-636.

38. Tian H, Li B, Evivie SE, Sarker SK, Chowdhury S, Lu J, et al. 2018. Technological and genomic analysis of roles of the cell-envelope protease PrtS in yoghurt starter development. Int. J. Mol. Sci. 19: 1068-1085.

39. Bassi D, Cappa F, Gazzola S, Orrù L, Cocconcelli PS. 2017. Biofilm formation on stainless steel by Streptococcus thermophilus UC8547 in milk environments is mediated by the proteinase PrtS. Appl. Environ. Microbiol. 83: 1-12.

40. Akpemado KM, Bracquart PA. 1983. Uptake of branchedchain amino acids by Streptococcus thermophilus. Appl. Environ. Microbiol. 45: 136-140.

41. Heefner DL, Harold FM. 1982. ATP-driven sodium pump in Streptococcus faecalis. Proc. Nati. Acad. Sci. USA 79: 2798-2802.

42. Podbielski A, Bettina ABL. 1998. The group A streptococcal dipeptide permease (Dpp) is involved in the uptake of essential amino acids and affects the expression of cysteine protease. Mol. Microbiol. 28: 1323-1334.

43. Doeven MK, Kok J, Poolman B. 2005. Specificity and selectivity determinants of peptide transport in Lactococcus lactis and other microorganisms. Mol. Microbiol. 57: 640-649.

44. Lamarque M, Charbonnel P, Aubel D, Piard JC, Atlan D, Juillard V. 2004. A multifunction ABC transporter (Opt) contributes to diversity of peptide uptake specificity within the genus Lactococcus. J. Bateriol. 186: 6492-6500.

45. Garault P, Le Bars D, Besset C, Monnet V. 2002. Three oligopeptide-binding proteins are involved in the oligopeptide transport of Streptococcus thermophilus. J. Biol. Chem. 4: 32-39.

46. Gardan R, Besset C, Guillot A, Gitton C, Monnet V. 2009.The oligopeptide transport system is essential for the development of natural competence in Streptococcus thermophilus strain LMD-9. J. Bacteriol. 14: 4647-4655.

47. Gardan R, Besset C, Gitton C, Guillot A, Fontaine L, Hols P, et al. 2013. Extracellular life cycle of ComS, the competencestimulating peptide of Streptococcus thermophilus. J. Bacteriol. 
8: $1845-1855$.

48. Rul F, Monnet V. 1997. Presence of additional peptidases in Streptococcus thermophilus CNRZ 302 compared to Lactococcus lactis. J. Appl. Microbiol. 82: 695-704.

49. Rul F, Monnet V, Gripon JC. 1994. Purification and characterization of a general aminopeptidase (St-PepN) from Streptococcus salivarius subsp. thermophilus CNRZ302. J. Dairy Sci. 77: 2880-2889.

50. Niven GW, Holder SA, Stroman P. 1995. A study of the substrate specificity of aminopeptidase $\mathrm{N}$ from Lactococcus lactis subsp. cremoris Wg2. Appl. Microbiol. Biotechnol. 44: 100-105.

51. Chavagnat F, Casey MG, Meyer J. 1999. Purification, characterization, gene cloning, sequencing, and overexpression of aminopeptidase $\mathrm{N}$ from Streptococcus thermophilus A. Appl. Environ. Microbiol. 65: 3001-3007.

52. Sieuwerts S, Molenaar D, van Hijum SAFT, Beerthuyzen M, Stevens MJA, Janssen PWM, et al. 2010. Mixed-culture transcriptome analysis reveals the molecular basis of mixedculture growth in Streptococcus thermophilus and Lactobacillus bulgaricus. Appl. Environ. Microbiol. 76: 7775-7784.

53. Tan PS, van Alen-Boerrigter IJ, Poolman B, Seizen RJ, de Vos WM, Konings WN. 1992. Characterization of the Lactococcus lactis papN gene encoding an aminopeptidase homologous to mammalian aminopeptidase N. FEBS Lett. 306: 9-16.

54. Klein JR, Klein U, Schad M, Plapp R. 1993. Cloning DNA sequence analysis and partial characterization of pepN a lysis aminopeptidase from Lactobacillus delbrúckii subsp. Lactis DSM7290. Eur. J. Biochem. 217: 105-114

55. Christensen JE, Lin D, Palva A, Steele JL. 1995. Sequence analysis, distribution and expression of an aminopeptidase $\mathrm{N}$-encoding gene from Lactobacillus helveticus CNRZ32. Gene 155: 89-93

56. Chapot-Chartier MP, Rul F, Nardi M, Gripon JC. 1994. Gene cloning and characterization of PepC, a cysteine aminopeptidase from Streptococcus thermophilus, with sequence similarity to the eukaryotic bleomycin hydrolase. Eur. J. Biochem. 224: 497-506

57. Motoshima H, Kaminagawa S. 2013. Aminopeptidase T, pp. 1674-1677. In Rawling, DN, Salvesen G (eds.), Handbook of Proteolytic Enzymes, 3rd Ed. Academic Press, California, USA.

58. Fernández-Espla MD, Rul F. 1999. PepS from Streptococcus thermophilus a new member of the aminopeptidaset family of thermophilic bacteria. Eur. J. Biochem. 263: 502-510.

59. Liu F, Du L, Du P, Huo G. 2009. Possible promoter regions within the proteolytic system in Streptococcus thermophilus and their interaction with the CodY homolog. FEMS Microbiol.
Lett. 297: 164-172.

60. Simonen M, Palva I. 1993. Protein secretion in Bacillus species. Microbiol. Rev. 57: 109-137.

61. Adda J, Gripon JC, Vassal L. 1982. The chemistry of flavour and texture development in cheese. Food Chem. 9: 115-129.

62. Dunn HC, Lindsay RC. 1985. Evaluation of the role of microbial Strecker-derived aroma compounds in uncleantype flavours of Cheddar cheese. J. Dairy Sci. 68: 2859-2874.

63. Lee CW, Desmazeaud MJ. 1985. Utilization of aromatic amino acids as nitrogen sources in Brevibacterium linens: an inducible aromatic amino acid aminotransferase. Arch. Microbiol. 140: 331-337.

64. Tsakalidou E, Anastasiou R, Papadimitriou K, Manolopoulou E, Kalantzopoulos G. 1997. Purification and characterisation of an intracellular X-prolyl-dipeptidyl aminopeptidase from Streptococcus thermophilus ACA-DC 4. J. Biotechnol. 59: 203-211.

65. Anastasiou R, Papadelli M, Georgalaki MD, Kalantzopoulos G, Tsakalidou E. 2002. Cloning and sequencing of the gene encoding X-prolyl-dipeptidyl aminopeptidase (PepX) from Streptococcus thermophilus strain ACA-DC4. J. Appl. Microbiol. 93: 52-59.

66. Deutsch SM, Molle D, Gagnaire V, Piot M, Atlan D, Lortal S. 2000. Hydrolysis of sequenced $\beta$-casein peptides provides new insight into peptidase activity from thermophilic lactic acid bacteria and highlights intrinsic resistance of phosphopeptides. Appl. Environ. Microbiol. 12: 5360-5367.

67. Meyer J, Jordi R. 1987. Purification and characterization of X-prolyl-dipeptidyl-aminopeptidase from Lactobacillus lactis and from Streptococcus thermophilus. J. Dairy Sci. 70: 738-745.

68. Atlan D, Laloi P, Portalier R. 1990. X-prolyl-dipeptidyl aminopeptidase of Lactobacillus delbrueckii subsp. bulgaricus: characterization of the enzyme and isolation of deficient mutants. Appl. Environ. Microbiol. 56: 2174-2179.

69. Khalid NM, Marth EH. 1990 Purification and characterization of prolyl-dipeptidyl aminopeptidase from Lactobacillus helveticus CNRZ32. Appl. Environ. Microbiol. 56: 381-388.

70. Bockelmann W, Fobker M, Teuber M. 1991 Purification and characterisation of the X-prolyl-dipeptidyl-aminopeptidase from Lactobacillus delbrueckii subsp. bulgaricus and Lactobacillus acidophilus. Int. Dairy J. 1: 51-66.

71. Giannoglou M, Alexandrakis Z, Stavros P, Katsaros G, Katapodis P, Nounesis G, et al, 2018. Effect of high pressure on modifications and enzymatic activity of a purified X-prolyl dipeptidyl aminopeptidase from Streptococcus thermophilus. Food Chem. 248: 304-311.

72. Chavagnat F, Meyer J, Casey MG. 2000. Purification, characterisation, cloning and sequencing of the gene encoding oligopeptidase PepO from Streptococcus thermophilus A. FEMS Microbiol Lett. 191: 79-85. 